EPRA International Journal of Economic and Business Review-Peer Reviewed Journal

Volume - 9, Issue - 5, May 2021 | e-ISSN: 2347 - 9671| p- ISSN: 2349 - 0187

\title{
EXPLORING MAHARASHTRA BUDDHIST TOURISM: A DESCRIPTIVE STUDY
}

\author{
Mr. Gotpagar Rahul Vijay \\ Assistant Professor, Deccan Education Society's, Pune, Chintamanrao College of Commerce, \\ Sangli. -416416(MH).
}

\section{ABSTRACT \\ DOI No: $10.36713 /$ epra7198 \\ Article DOI URL: https://doi.org/10.36713/epra7198}

This study considers which factors are strengthen Maharashtra Buddhist Tourism and to address the problems faced by Maharashtra Buddhist tourism. It also crucially evaluates Maharashtra Tourism Statistics by availing secondary information's by using various methods. There is Buddhist establishment in entire Maharashtra which has been facing various problems may be economic and non-economic which could be sincere attempt to discuss in this research paper. Maharashtra has unique and diverse culture in the sense of socio eco diversity. But some hurdles have been facing by Maharashtra. One can easily sort out lower growth of Buddhist Tourism in Maharashtra.

KEYWORDS - Buddhist Caves, Buddha Vihara, Buddhist Tourism, Shraman Sanskriti etc.

\section{INTRODUCTION}

Maharashtra is a major state in India. It contributes higher economic share towards country's national income. Maharashtra is a state in the region of India and is the nation's third largest state by area and is also the world's second most populous sub national entity. It has over 110 million inhabitants and its capital, Mumbai, has a population of approximately 18 million. Nagpur serves as second capital as well as winter capital of the state. Maharashtra's business opportunities along with its potential to offer a higher standard of living attract migrants from all over India.

Spread over 118809 sq. mi. (307710 km sq2.) it is bordered by the Arabian Sea to the west and the Indian states of Karnataka, Telangana, Goa, Gujarat,
Chhattisgarh, Madhya Pradesh and UT Dadra and Nagar Haveli.

Coming to Maharashtra, it has lately become alive to the need for boosting tourism. Tourism can become a powerful growth engine for the Maharashtra economy only within efficient tourism infrastructure in place. Tourism \&Tourism Infrastructure coverage is vast and growing. It encompasses both soft as well as physical infrastructure and contains a variety of facilities. Tourism these require soft infrastructure which includes mainly governance aspects especially observance of just in time principle, least wastages, quality \& suitable skills, best management norms and experience of a healthy swatch life. 


\section{OBJECTIVE}

1. To study various Buddhist tourist destinations within Maharashtra state

2. To show the importance of Buddhist tourism in Maharashtra

3. To discuss problem faced by Buddhist tourist destinations in Maharashtra state and addressing its issues.

\section{METHODOLOGY}

This research paper entirely secondary data which is collected from various sources like Text books, Reference books, Websites, Articles Presented in online Newspapers etc. Also, this paper has descriptive discussion in nature.

\section{Regions Divisions and Districts}

Maharashtra came into existence on May 1, 1960 (also known as Maharashtra Day), initially with 26 districts. Ten new districts have been created since then, and currently the numbers of districts in the state are 36. These districts are grouped into six administrative divisions as follows- Amravati, Aurangabad, Konkan, Nagpur, Nashik and pune. Geographically, historically and according to political sentiments, Maharashtra has six main regions: Vidharbha, Marathwada, Khandesh and Northern Maharashtra, Pune, Konkan and Nashik.

Before studying every element of Maharashtra Buddhist tourism, one need to understand Maharashtra's entire Buddhist establishment which is spread over all region in state itself. For proper understanding of this Buddhist foundations we have following hexagon that depicts essence of enriched Buddhism.

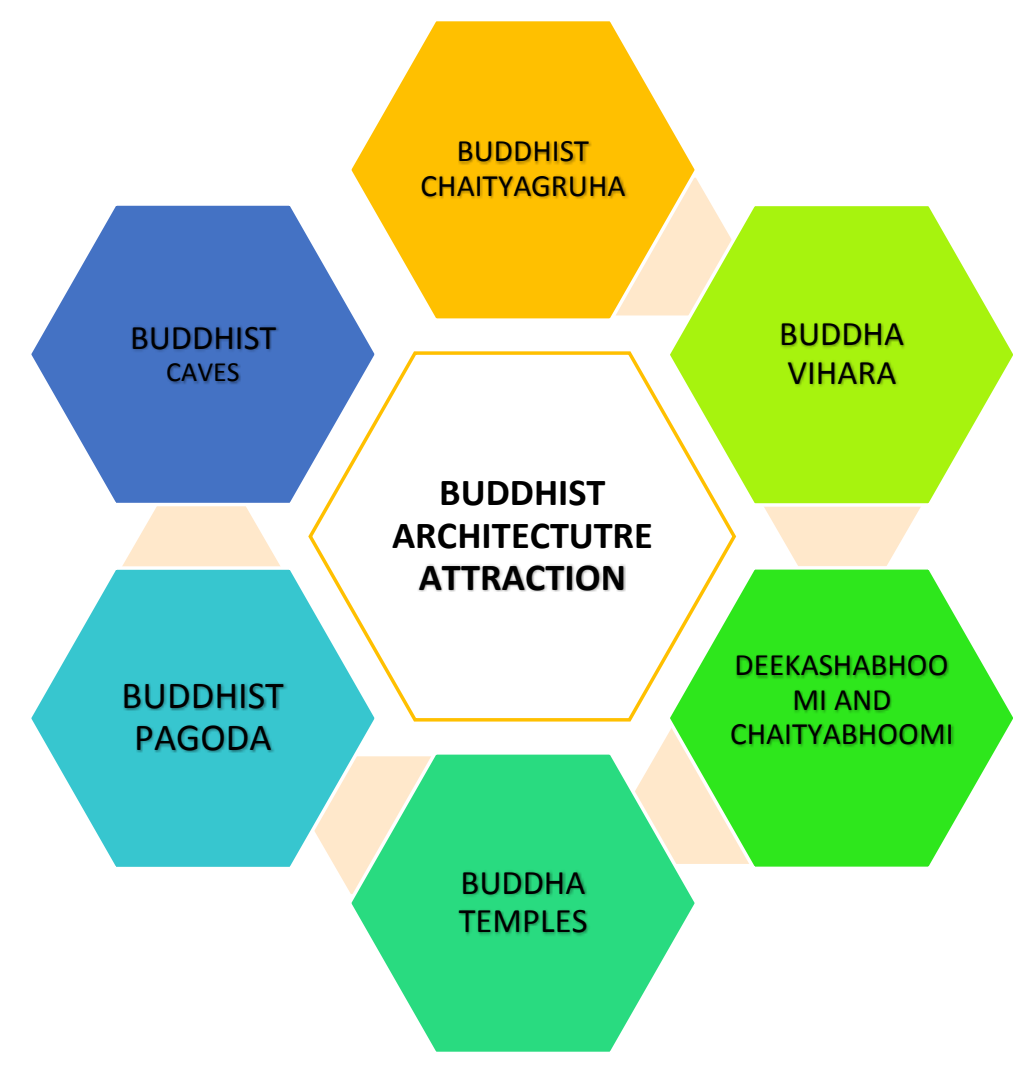

\section{MAJOR BUDDHIST TOURIST ATTRACTIONS}

Every year lakhs of tourist have come in Maharashtra for visit to Buddhist attractions. The tourist came from Thailand, Sri Lanka, China, Laos, Tibet, Indonesia, USA, Japan, Korean Peninsula, Australia, Afghanistan, Maldives, Australia, USSR, Magnolia, African Nations etc. some of which are tourist either pilgrimages. Other personalities like Historian and Buddhist Intellectuals have larger interest in exploring Buddhist establishment in diverse Maharashtra. They visited following buddhist architectures and studied various issues related with beautiful Maharashtra Buddhist culture. Following is hexagonal that depicts various form of Buddhist 
establishment famous in all over Maharashtra as well as

in world.

\section{FAMOUS BUDDHIST CAVES IN MAHARASHTRA}

Ajanta Caves, Ajanta, Aurangabad district, Aurangabad Caves Aurangabad, Bahrot Caves, Dahanu, Thane district, Bedse Caves Maval, Pune district, Bhaja Caves Maval, Pune distric , Bhatala Caves Chandrapur, Vidarbha Maharashtra 5th Century CE, Elephanta Caves, Elephanta Island, Mumbai, Ellora Caves Aurangabad district Gandharpale Caves, Ghatotkacha Cave, Janjala Village,Sillod, Aurangabad District, Ghorawadi Caves, Kanheri Caves, Borivali, Mumbai Buddhist Caves, Karad Caves, Satara District, Karla Caves, Kharosa, Kondana Caves, Kuda Caves, Lenyadri Caves, Mahakali Caves, Mandapeshwar Caves Borivali, Mumbai, Nadsur Caves, Nenavali Caves, Panhalakaji Caves, PataleshwarPune City, Shelarwadi Caves, Shivleni Caves, Ambajogai, Shirwal Caves, Shivneri Caves, Thanale Caves, Tulja Caves, Wai Caves.

Source-https://en.wikipedia.org/wiki/List_of_caves_in_Maharashtra

\section{BUDDHAVIHARA IN MAHARASHTRA}

Vihara generally refers to a monastery for Buddhist renunciates. The concept is ancient and in early Sanskrit and Pali texts, it meant any arrangement of space or facilities for dwellings. ${ }^{[2][3]}$ The term evolved into an architectural concept wherein it refers to living quarters for monks with an open shared space or courtyard, particularly in Buddhism. The term is also found in Ajivika, Hindu and Jain monastic literature, usually referring to temporary refuge for wandering monks or nuns during the annual Indian monsoons. ${ }^{[2][4][5]}$ In modern Jainism, the monks continue to wander from town to town except during the rainy season (Chaturmas), the term "vihara" refers their wanderings. [6][7]. Vihara or vihara hall has a more specific meaning in the architecture of India, especially ancient Indian rock-cut architecture. Here it means a central hall, with small cells connected to it sometimes with beds carved from the stone.

\section{Approximately 739 Buddhavihara in Maharashtra}

Mumbai (117), Pune (138), Ahmadnagar (5), Amravati (25), Nagpur (56), Thane (49), Jalna (17), Parbhani (14), Nanded (32), Beed (17), Washim (14), Nashik (21), Latur (12), Yavatmal (14), Aurangabad (54), Osmanabad (9), Jalgaon (4), Akola (22), Kolhapur (4), Buldhana (46), Solapur (6), Hingoli (11), Chandrapur (8), Sangli (4), Ratnagiri (4), Bhandara (8), Raigad (4), Wardha (5), Gondia (3), Lalitpur (4) Narayangaon (1), Jintur (1), Kothali (1), Mukhed (1), Titwala (1), Jamner (1), (1), Phaltan (1), Sindhudurg (2), Adilabad (2), Rahuri (1), Buldana (1), Palghar (2).

Source-http://navayan.com/buddhavihar.php?stateid=1\&state=maharashtra

\section{ANALYSIS AND DISCUSSION}

Following table considers Table considers the top ten states and union territories in India for receipt of foreign tourists, categorizing each as a percentage of the overall visits by foreign tourists in 2017. As illustrated, in 2017, Maharashtra was ranked first among Indian states with a $18.90 \%$ share of foreign tourist visitors to India. Despite its many worldrenowned Buddhist pilgrimage sites, it attracted just over a million foreign tourists in that year. That number, along with tourism to Buddhist sites in general, is expected to rise in the future as a result of the Ministry of Tourism's Proactive Promotion campaign. For example, the ministry has developed the tourism capacity of the ancient city of Aurangabad, making it a Buddhist destination for visitors from Southeast Asian nations. Travel agency websites, electronic media campaigns, travel publications, and the official website of the Ministry of Tourism all offer information about visiting the area and serve as a means of attracting foreign tourists to the state's Buddhist circuit.

\section{Table- 1. Share of top 10 states/ UTs of India in Number of Foreign Tourist Visits in 2017}

\begin{tabular}{|c|c|c|c|}
\hline \multirow{2}{*}{ Rank } & \multirow{2}{*}{ State/UT } & \multicolumn{2}{|c|}{ Foreign tourist visits in 2017 } \\
\cline { 3 - 4 } & & Number & Percentage Share (\%) \\
\hline 1 & Maharashtra & 5078514 & 18.9 \\
\hline 2 & Tamil Nadu & 4860455 & 18.1 \\
\hline 3 & Uttar Pradesh & 3556204 & 13.2 \\
\hline 4 & Delhi & 2740502 & 10.2 \\
\hline 5 & Rajasthan & 1609963 & 6.0 \\
\hline 6 & West Bengal & 1574915 & 5.9 \\
\hline
\end{tabular}




\begin{tabular}{|c|c|c|c|}
\hline 7 & Punjab & 1108635 & 4.1 \\
\hline 8 & Kerala & 1091870 & 4.0 \\
\hline 9 & Bihar & 1082705 & 4.0 \\
\hline 10 & Goa & 842220 & 3.1 \\
\hline & Total of top 10 & 23545983 & 87.6 \\
\hline & Others & 3340655 & 12.4 \\
\hline \multicolumn{2}{|c|}{ Tource-Indian Tourism statistics at a glance 2018 http://tourism.gov.in/sites/ } \\
\hline
\end{tabular}

\section{GOVERNMENT OF MAHARASHTRA INITIATIVES}

Maharashtra tourism Developments Corporation (MTDC) has decided to offer some of its land to Buddhist countries for the development of monasteries and Buddhist theme parks. The decision was taken during an International Buddhist Conclave that was held a few days back in Aurangabad (2018) in association with the Union Tourism Ministry. The aim was to promote the city of Aurangabad and its treasure, Ajanta Ellora caves (the UNESCO heritage site) as one of the prime Buddhist attractions in the world. Besides, the MTDC is hoping to strengthen its bonds with other countries following Buddhism by promoting Maharashtra as a major Buddhist state in India. The land of Maharashtra has a rich Buddhist heritage and culture. Maharashtra plans to offer land in Aurangabad Caves, to Buddhist countries so that they can develop theme park and monasteries in the region. Besides, Ajanta Ellora, MTDC is also encouraging local bodies to build Buddhist Circuits in the state such as Global Vipassana Pagoda in Gorai, Karla and Bhaja Caves in Pune, Stupa in Nalasopara, Deekshabhoomi in Nagpur and Chaityabhoomi in Dadar Mumbai.

\section{STRENGTH OF MAHARASHTRA BUDDHIST TOURISM}

1. Maharashtra Natural Beauty-

Maharashtra already have flourishing and enriched Natural Beauty and its associated with Ancient caves, Ancient Temples that have marvelous impact on expanding buddhist tourism in Maharashtra as per requirement of International Standards.

\section{Maharashtra Buddhist Infrastructure-}

Maharashtra state has unique buddhist infrastructure that had been carved out since Ancient time. Such as Ancient Buddhist Caves, Buddha Vihara, Buddha Temples, Modern Buddha Pagodas, Buddhist meditation Centre it could be beneficial for Government to formulates Tourism policies for maintaining and preserving buddhist culture on large scales.

\section{Maharashtra Buddhist Rejuvenation}

Movement-

World Leader Bharat Ratna Dr. Babasaheb Ambedkar initiated Buddhism Movement with his extraordinary buddhist knowledge. He Rejuvenated Buddhism and Neo Buddhism, he refined conservative Buddhist philosophy and gave modern and scientific approach to it.So this is the best platform to expand Buddhist Tourism with the help of his perception and his ideas. Maharashtra government will have chance to create new policies for Buddhist tourism.

\section{Peoples participation in Mass Buddhist} Conversion-

Dr. Ambedkar had started mass conversion of marginalized sections of peoples into Neo Buddhist Religion that is Buddha Dhamma. Basically, this not conversions it was form of searching our hidden identity by way of scientific philosophy and peaceful nature of religious movement. That's why this is a great achievement for enriching buddhist tourism and it is great strength of buddhist tourism views.

\section{Maharashtra Shraman Sanskriti (Monk culture)-}

Maharashtra continues to preserve Shraman Sanskriti but it has been limited on scale. It requires strong dedications, thought purity, renunciations of physical attractions etc. sometimes it is problematic for buddhist peoples but it need to be maintained continually by way of Monk education, Monk visits to homes, Monks modernistic buddhist prays etc. so it can be fruitful for growing of buddhist tourism.

\section{PROBLEMS ASSOCIATED WITH MAHARASHTRA BUDDHIST TOURISM}

\section{Infrastructural Problem-}

Maharashtra government has lack of Infrastructural Policies. Maharashtra government totally responsible for various infrastructural problems associated with buddhist tourism in Maharashtra. Some destinations like Aurangabad Buddhist Caves have been facing rail, road bottlenecks near to this place. Even this place does not have simple 10x10 road from centre of the city towards Aurangabad Caves. Since last 70 years this city has been facing same problem even after various government promises.

\section{Religious Propaganda-}

Maharashtra state has various cultural identity status. Different ethnic types of peoples have been residing in Maharashtra since ancient period. Maharashtra has 
Hindu, Muslim, Christian, Buddhist, Parsi, Sikh, Sindhis, and Lingayat etc. out of which Hindus are dominant class which are confronting with other community for preserving their dominance in entire Maharashtra. Hindu political leaders have been always opposed Buddhist developmental policies. One can easily get the information about religious discrimination in Maharashtra's villages. Hindu autocratic propaganda always harms to buddhist religious tourism by abrogating their funds.

\section{Economical Problems-}

Maharashtra Buddhist tourism facing economical problems on large scale. Every establishment requires large amount of funding so it can be beneficial for canvassing dream projects. Government is not ready to disburse large amount of money for their developments.

\section{Discriminatory political will power-}

Every time state government and their political representative don't show their aggressive will power for buddhist tourism. Political leaders are also religious leaders. Hence, they always diverted buddhist tourism funds towards other activity and then buddhist tourism faced complex problems due to their political behaviour.

\section{Lack of Private Participations-}

Maharashtra state doesn't show optimistic views for buddhist tourism. Government always opposed private participation in this destination. Private partnership doesn't mean capital participation. Simply it means Local, small scale stakeholders participation in buddhist tourism.

\section{Lack of Advertising system-}

Buddhist tourism of Maharashtra lack of advertising facilities. State government is narrowed down their views about buddhist tourism. They always advertise only political news. This infrastructure facing media, multimedia and print media problems.

\section{International Stage-}

There is no necessity to getting knows about Maharashtra buddhist tourism spots to International peoples. International tourist knows each and every fact about Buddhist caves, Buddhist temples, buddhist pagodas spreading over Maharashtra. But it requires internationally standard services associated with this tourist places.

\section{ADDRESSING PROBLEMS ASSOCIATED WITH BUDDHIST TOURISM IN MAHARASHTRA}

1. Maharashtra's Tourism Strategy

- For achieving sartorial growth of $10 \%$ p.a. and share of $15 \%$ in GSDP

1. Encouraging Mega Project investments especially in less developed tourism zones with high potential

2. Monetization of existing land bank with MTDC
3. Improving tourism infrastructure throughout the state by various concerned departments;

4. Investor facilitation and ease of doing business.

2. Forcreating1millionadditional jobs in the tourism sector

1. Increased focus on Mega and MSME tourism units.

2. Offer additional incentives to employmentintensive Mega units.

3. Leverage state and central skill development schemes.

4. Consider Agro \& Rural, Adventure sports, events based tourism activities etc. as a thrust sector.

5. Promotion of tourism as an attractive sector for employment.

\section{Development of Tourism growth corridors}

1. Classify the state into separate tourist cities, tourist clusters and tourist corridors which will be promoted through identified themes.

2. Employ a pilot project along a major highway and on its successful returns, replicate the process along five major highways in the state.

\section{Development of Special Tourism Districts/Zones}

1. The districts of Nagpur, Aurangabad and Sindhudurg will be earmarked as special tourism districts.

2. In addition, the state will notify other special tourism zones/estates as when required.

3. These regions will be given additional incentives and incentive period.

4. In addition, special marketing assistance will be given to them to promote them as major tourism destinations of the state.

\section{Public Private Partnership Model for growth in} Tourism Sector

1. The Department of Tourism, Government of Maharashtra will Identify and develop shelf of projects and under take these projects through the PPP/JV mode.

\section{Five Step Approach for Marketing and Promotion-}

1. Develop an integrated 360-degree marketing plan.

2. Participation in international road shows/ fairs/ G2B meeting setc.

3. Develop a world class website for Maharashtra tourism.

4. Develop brand equity of the state through theme based tourism.

5. Special incentives to media which promote Maharashtra tourism. 
LIMITATIONS- This research paper is depend upon some type of secondary data and limited responses from interview methods. There may be another chances of studying various factors enshrined in this paper but this data can be limited to study of Buddhist tourism only within Maharashtra. Chances of criticism should be possible but we are always welcoming the opinions from various stakeholders of society. Buddhist tourism study required various financial resources for broad and technical explanations but this is loyal attempt from us to display present condition of this less explored sections.

\section{CONCLUSION}

For providing state of the art tourism infrastructure, the state needs to attract private sector participation for infrastructure development projects and access the operational expertise of private companies under public private partnerships (PPPs) model for implementation infrastructure projects efficiently. For this, identification of suitable private partners for projects in the state is a must. Structures and mechanisms need to be created to provide advice on project marketing and deal structuring, Transaction Advisory Services for the public sector to engage private investors, bid management services for Investors, identify optimal capital structures and financing strategies for PPP projects, assist clients in packaging projects in order to raise capital through various debt or equity structures and instruments, create business plans, secure financing for infrastructure projects as per the safety standards, valuation and business modeling, divestitures and carve-outs and feasibility studies. Tourism needs socio-political acceptance by those who run the state. And a growing belief that the rapid development of the tourism industry will bring in multifold benefits such as development of the rural interiors and regional areas, economic growth and wealth creation. We can also take into account employment generation in rural areas, adding substantially to exports and domestic revenues. Maharashtra Buddhist tourism is waiting to welcome you with open arms.

\section{REFERENCES}

1. Sharon La Boda (1994). International Dictionary of Historic Places: Asia and Oceania. Taylor \& Francis. p. 625. ISBN 978-1-884964-04-6.

2. Vihara, MonierMonier Williams, Sanskrit-English Dictionary Etymologically Arranged, Oxford University Press, p. 1003

3. "He now undertook what were described as 'dharma yatras' instead of the usual royal 'vihara yatras'. Vihara yatras were marked by pleasures such as the hunt" in NayanjotLahiri (2015). Ashoka in Ancient India. Harvard University Press. pp. 181-183. ISBN 978-0-674-91525-1.

4. Stella Kramrisch (1946). The Hindu Temple. Princeton University Press (Reprint: MotilalBanarsidass). pp. 137-138. ISBN 978-81208-0223-0.

5. Paul Dundas (2003). The Jains. Routledge. pp. 203-204. ISBN 1-134-50165-X.

6. Gomațeśvarasahasrābdìmahotsavadarśana,NirajJa in,ŚravanabelagolaDigambaraJainaMuzaraīInsțitty uśamsaMainejingaKamețī, 1984, p. 265

7. Tulasīprajñā, JainaViśvaBhāratī, 1984, p. 29

8. Sanjay Kumar Pandagale PAC 16.01 (2015-16) "A study of educational status and Issues of Buddhists/Neo-Buddhists students of Maharashtra at elementary level", NCERT publication.

9. https://timesofindia.indiatimes.com/travel/destinati ons/maharashtra-to-be-the-next-budhist-hubsoon/as65873929.cms

10. https://www.india.com/travel/articles/buddhapurnima-2017-12-famous-buddhist-caves-inmaharashtra-3230071

11. Revised Lists Of Antiquarian Remains in The Bombay Presidency. 1897. p. 285.

12. "ASI Mumbai Circle". www.asimumbaicircle.com 